\title{
Analysis of the Financial Soundness of Footwear Industry in Bangladesh: An Empirical Study using Z-score
}

\author{
Ishrat Jahan $^{1^{*}}$, Fareen Zaman ${ }^{2}$ \\ ${ }^{1}$ Assistant Professor, School of Business \& Economics, United International University, Dhaka, BANGLADESH \\ ${ }^{2}$ Senior Lecturer, School of Business \& Economics, United International University, Dhaka, BANGLADESH \\ *Corresponding Contact: \\ Email: ishrat_jahan@bus.uiu.ac.bd
}

\begin{abstract}
Among all the available statistical techniques, Altman's Z-score is found to be the most reliable technique to measure the financial soundness of any given business organization. In this paper, we have selected footwear industry which is the second largest foreign currency earner in Bangladesh. This industry is contributing in a greater scale to the economy of our country. The prime objective of this study is to assess the financial heath, i.e. analyze the probability of bankruptcy of the listed companies of the footwear industry. We have studied the financial statements of five companies listed in the stock exchange for a period of 2011 to 2015. The study revealed that the footwear industry overall is in a safe position i.e. financially sound, showing two of the selected companies in the safe zone, one in the grey zone and two in the distress zone. The findings of the study will help different groups of stakeholders to make decisions regarding their investments and other choices, considering the soundness of this specific industry.
\end{abstract}

Key Words: Footwear industry, financial health, Altman's Z-Score, bankruptcy

\section{INTRODUCTION}

The stakeholders are always concerned about the financial soundness and stability of a business firm. For example, investors are interested to know the liquidity of the firm; creditors want to know the solvency of the firm etc. Financial statements prepared by companies are meant to provide its users with reliable information about a company's performance and financial position (Pandey, 2004). These statements provide large number of information to the stakeholders to judge the financial capacity of the business. The most significant statements to carry this information are: Statement of Profit \& Loss and other Comprehensive Income, Statement of Cash Flow and Balance Sheet.

To address interest of the stakeholders and to evaluate the financial performance of any company, Ratio Analysis is the most extensively used tool. Ratios present information in a manner which is easily understandable and comparable. The analysis of financial statements 
is a process of evaluating the relationship between the components of financial statements to obtain a better understanding of the firm's position and performance (Hossain and Moudud Ul Huq, 2014). In addition to this, Wood and Sangster (2002) opined that financial statements would be largely unusable without the ratios. The ratios are important because it provides with a scope to compare and assess performance from year to year within a firm and with of another firm as well. This helps the stakeholders to make different decisions.

Here, we have measured and analyzed the performance and financial health of Footwear Industry of Bangladesh using the Altman's Z-Score which is considered to be a reliable tool. This model is dedicated to predict possibilities of bankruptcy of manufacturing concerns. There is evidence that it has $76.9 \%$ accuracy in predicting bankruptcy of the underlying sample (Begley et al. 1996). Altman's Z-Score uses ratio analysis to predict bankruptcy and has proven to be accurate up to $90 \%$ (Chen and Shemerda, 1981).

Footwear industry is one of the oldest industries in Bangladesh with a significant contribution to the national economy of the country. This industry is flourishing because of the availability of local raw material, cheap labor, young workforce and large market. As a result there is a possibility of this industry to become the second largest foreign currency earner, after ready-made garments. According to the reports of Centre for Policy Dialogue (CPD), Bangladesh has earned USD 354.22 million from export of leather footwear in 2015 fiscal year. In this situation, this industry provides us with an opportunity to study the possibility of bankruptcy using the Altman's Z score.

\section{Objectives And Methodology}

The objectives of this study are:

- To assess the financial soundness and stability of the footwear industry of Bangladesh.

- To identify the possibility of bankruptcy of the footwear industry using Altman's Z-score.

This paper is focused on analyzing the financial health of the footwear industry of Bangladesh. As a result the data is mainly collected from the annual reports of the Dhaka Stock Exchange (DSE) and Chittagong Stock Exchange (CSE) listed footwear companies. The total number of listed companies of this industry is 5, namely; Bata, Apex Footwear, Apex Tannery, Legacy footwear and Samata. We are assessing the financial soundness and possibility of bankruptcy of these 5 companies. In addition to this, numerous numbers of articles from different journals, books, newspapers and websites have been studied for the purpose.

For analyzing the objective of this paper using Altman's Z-score, firstly we have calculated the mean and standard deviation of individual companies for a time frame of 2011 to 2015 and the industry as well. Secondly, we have applied these outcomes into the Z-score model. The model is given below:

$Z=1.2 \times 1+1.4 \times 2+3.3 \times 3+.6 \times 4+.999 \times 5$

Here,

$\mathrm{X} 1=\mathrm{WC} / \mathrm{TA}$

It is the ratio between the Working Capital (WC) and Total Asset (TA) of the firm. This ratio measures the liquid asset proportionate to the size of the company.

$\mathrm{X} 2=\mathrm{RE} / \mathrm{TA}$ 
This is the ratio between Retained Earnings (RE) and Total Asset (TA). It measures the profitability of the business. When a business has a good forecast of investment opportunities, it retains higher profit. So a firm which is financially sound will have a higher ratio.

$\mathrm{X} 3=\mathrm{EBIT} / \mathrm{TA}$

This is the ratio between Earnings before Interest and Taxes (EBIT) and Total Asset (TA). The value of this ratio signifies the capacity of the firm to generate enough earnings to pay the interest and borrowings. The higher is the ratio, the higher is the capacity pay the interest against borrowing of the company.

X4 = MVE/BVD

This is the ratio between the Market Value of Equity (MVE) and Book Value of Debt (BVD). This ratio indicates that there is a direct impact of a firm's financial health on the price of shares in the market.

$\mathrm{X} 5=\mathrm{S} / \mathrm{TA}$

This is the ratio between Sales (S) and Total Asset (TA). It is the measure of the firm's efficient use of its asset into generating sales revenue. The higher value of the ratio provides evidence of better capacity of the organization to generate revenue.

The possibility of bankruptcy of a company depends on the value obtained by using this above stated formula where, the following assumptions will be applicable to conclude the outcome of Z-score:

If, $Z>2.99$, then the business is financially sound and healthy and there is least probability that the firm will face financial distress; namely safe zone.

If, $\mathrm{Z}<1.80$, then there is a high probability that the business will face financial distress in near future and the business may need desperate measures (such as mergers) to survive in the market; namely distress zone; and

If, $1.8<Z<2.99$, then the business has less probability to face financial distress in the near future, namely gray zone.

\section{LITERATURE REVIEW}

Investors need information to help them to decide whether they should buy, hold or sell. Furthermore, investors are interested in financial information that enables them to assess the ability of the firm to pay dividends (i.e., return on investment) for their stocks (Helfert, 1991).

Financial statements analysis is very much essential to lenders, security analyst, managers and others (Prasanna, 1995). The employees and their representatives are interested in information about the stability and profitability of their employer's. Lenders are interested in information that helps them determine if their loans will be paid when due. Suppliers or trade creditors providing goods and services are interested in information that enables them to decide whether to sell to the enterprise and to determine whether amounts owed to them will be paid when due. Creditors are likely to be interested in an enterprise over a shorter period than lenders unless, they depend on the enterprise as a major, continuing customer (Horne and James, 1998).

Financial analysis is the process of identifying the financial strength and weaknesses of the firm by properly establishing relationship between the items of the balance sheet and the profit and loss account (Pandey, 1979). Financial ratios are the easiest method to evaluate the 
financial performance of the company. It can be used to analyze the firm's liquidity, profitability and solvency (Wen-Cheng LIN, 2005). Hannan and Shaheed (1979) used financial ratios to show the financial position and performance analysis of Bangladesh Shilpa Bank. They showed that techniques of financial analysis can be used in the evaluation of financial position and performance of financial institution as well as non-financial institutions even Development Financial Institutions (DFI). Operational performance of limited companies was measured using financial ratios by Jahur and Uddin (1995). They used profitability, liquidity, activity and capital structure to assess the performance.

Altman (1968) used ratio analysis to predict corporate bankruptcy. But there are also several researchers who used different models to predict bankruptcy (Altman 1968; Zmijewski 1984; Kida 1998; Shirata 1998; Shumway 2001 etc.). Researchers have compared different bankruptcy models (i.e. Uni variate, MDA, Logit, etc.) and have concluded that despite certain practical and theoretical limitations, the Altman method is superior due to its simplicity, practicality, and accuracy (Collins, 1980; Mossman et al, 1998).

Altman studied 33 different publicly traded manufacturing companies between 1946 and 1965 to analyze the possibility of bankruptcy using an equation named Z-score model which correctly showed $94 \%$ as bankrupt companies and $97 \%$ of potential bankruptcy prior one year. Many other researchers followed the Altman Z-score thereafter to assess bankruptcy of different industries. For example, Ramaratnam and Jayaraman (2010) analyzed Indian steel industry based on a 5 (five) year period and found the selected companies are financially sound. Alkhatib and Al Bzour (2011) analyzed Jordanian listed companies using 16 (sixteen) years' data from 1990 to 2006. They found 93.8\% accuracy in predicting bankruptcy using Altman's Z-score, 5 years prior to liquidation. Al-Rawi, Kiani and Vedd (2008) applied Altman's Z-score model on Jordan Establishment for Marketing Durable Goods for bankruptcy prediction for the period 2002-2004. The Z-score was less than 1.81 and their finding was that the company will be facing bankruptcy in the near future due to its increased debt.

Altman's Z-score model has also been applied in Bangladesh as well. Jahur and Parveen (1996) applied this model on Chittagong Steel Mills Ltd. and found the possibility of bankruptcy due to unrealistic goals, strict govt. regulations and interventions. Mizan et al. (2011) applied Z-score to assess the bankruptcy of Pharmaceutical Industry selecting 6 leading companies where the finding was that two of these companies are found to be financially sound and other companies are found prone to financial distress. Mizan and Hossain (2014) conducted a study on all listed cement companies in Bangladesh to predict the bankruptcy using Z-score model. The outcome of the study was that, Heidelberg Cement and Confidence Cement are financially sound, whereas Meghna Cement Mills, Aramit Cement and Lafarge Surma Cement are not in a good position. Hossain and Haq (2014) also analyzed the Cement Industry using the same model and concluded that the overall position of the industry is not satisfactory.

\section{FINDINGS AND ANALYSIS}

In this study, we have used the Altman's Z-score model. The Table 1 represents the ratio between Net Working Capital and Total Asset. This ratio is important to assess the liquidity of the individual company. The NWC/TA indicates the ability to meet the immediate short term obligations of the company, with cash. According to our findings, Legacy shows the highest mean value of $55.4 \%$ which indicates the efficient management of working capital. On the contrary, Apex Footwear reveals the mean value of below $10 \%(8 \%)$ which shows inefficiency. Other 3 companies show a good maintenance of working capital. The industry average shows $34.96 \%$ which is a good indicator of efficient management of working capital of the overall footwear industry. 
Table: 1

\begin{tabular}{|lcccccc|}
\hline Year & Bata & Apex footwear & Apex tannery & Legacy & Samata & Industry mean \\
\hline $2010-2011$ & 0.27 & 0.01 & 0.46 & 0.52 & 0.09 & 0.27 \\
$2011-2012$ & 0.25 & 0.12 & 0.49 & 0.54 & 0.11 & 0.302 \\
$2012-2013$ & 0.29 & 0.12 & 0.56 & 0.58 & 0.5 & 0.41 \\
$2013-2014$ & 0.33 & 0.11 & 0.56 & 0.54 & 0.49 & 0.406 \\
$2014-2015$ & 0.38 & 0.05 & 0.34 & 0.59 & 0.44 & 0.36 \\
Mean & 0.304 & 0.082 & 0.482 & 0.554 & 0.326 & 0.3496 \\
Std. Deviation & 0.0518 & 0.0497 & 0.0907 & 0.0297 & 0.2077 & \\
\hline
\end{tabular}

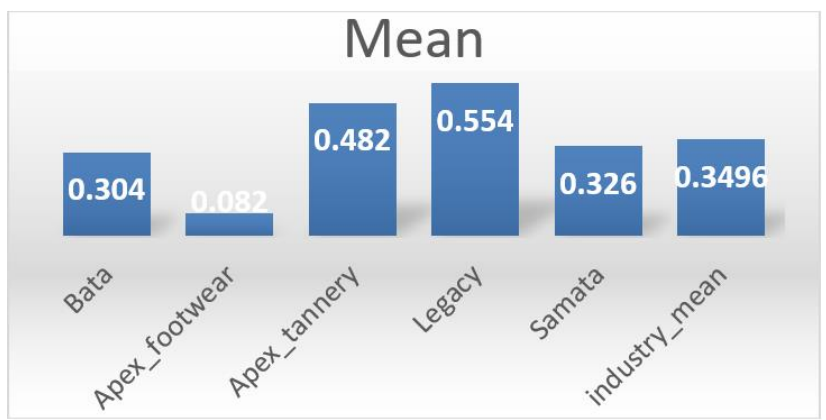

Figure 1: Average liquidity ratio

In table 2 we have represented the ratio of Retained earnings to total asset, which measures the profitability of the companies. This ratio explains the capacity of the company to generate profit i.e. earning. Here, Bata is in the best position showing a profitability of $42.2 \%$. Samata on the other hand, is found to incur losses in the consecutive years during the observed period. Legacy in this case is making very low profit consistently. The other two companies are found to be moderately profitable. The industry profitability ratio is $11 \%$ which means the industry is generating satisfactory profit.

Table: 2

\begin{tabular}{|lcccccc|}
\hline Year & Bata & Apex footwear & Apex tannery & Legacy & Samata & Industry mean \\
\hline $2010-2011$ & 0.26 & 0.31 & 0.18 & 0.001 & -0.22 & 0.1062 \\
$2011-2012$ & 0.4 & 0.31 & 0.22 & 0.0006 & -0.28 & 0.13012 \\
$2012-2013$ & 0.44 & 0.12 & 0.28 & 0.012 & -0.4 & 0.0904 \\
$2013-2014$ & 0.49 & 0.11 & 0.29 & 0.011 & -0.39 & 0.1022 \\
$2014-2015$ & 0.52 & 0.1 & 0.26 & 0.001 & -0.39 & 0.0982 \\
Mean & 0.422 & 0.19 & 0.246 & 0.0051 & -0.34 & 0.11 \\
Std. Deviation & 0.1016 & 0.1098 & 0.0456 & 0.0058 & 0.08 & \\
\hline
\end{tabular}

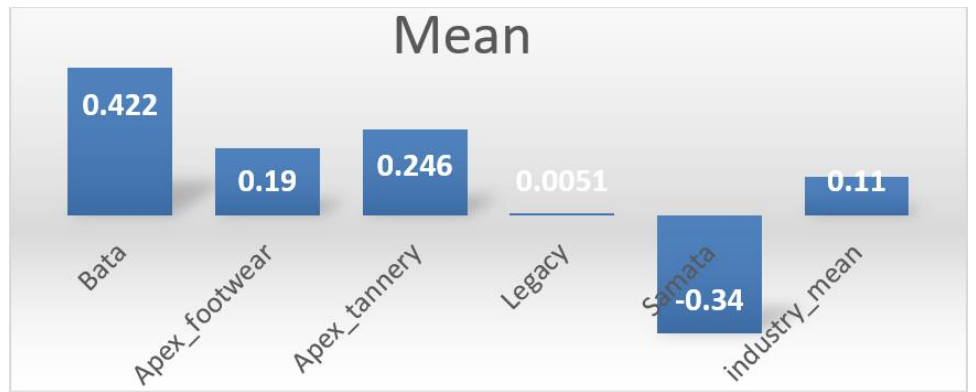

Figure 2: Average profitability ratio 
Table 3 represents the ratio between Earnings before interest and tax (EBIT) and Total assets (TA). This ratio analyzes how well a company can use its assets to generate sales, i.e. the efficiency ratio. For this ratio, we found Bata showing the highest mean value of $24.2 \%$ and lowest variation of $1.3 \%$, which indicates generation of very consistent profit generating capacity. Samata is with the lowest mean value of $1 \%$. Among the other 3 companies, Apex Footwear shows satisfactory above average mean value $(15.4 \%)$ and rest 2 show below average score. The average industry mean is $10.08 \%$, indicating a reasonable performance.

Table: 3

\begin{tabular}{|lcccccc|}
\hline Year & Bata & Apex footwear & Apex tannery & Legacy & Samata & Industry mean \\
\hline $2010-2011$ & 0.24 & 0.3 & 0.07 & 0.04 & -0.002 & 0.1296 \\
$2011-2012$ & 0.25 & 0.27 & 0.08 & 0.02 & -0.0004 & 0.12386 \\
$2012-2013$ & 0.26 & 0.09 & 0.09 & 0.019 & 0.032 & 0.0982 \\
$2013-2014$ & 0.23 & 0.06 & 0.07 & 0.022 & 0.004 & 0.0772 \\
$2014-2015$ & 0.23 & 0.05 & 0.07 & 0.014 & 0.012 & 0.0752 \\
Mean & 0.242 & 0.154 & 0.076 & 0.023 & 0.01 & 0.100812 \\
Std. Deviation & 0.013 & 0.121 & 0.0089 & 0.0099 & 0.0139 & \\
\hline
\end{tabular}

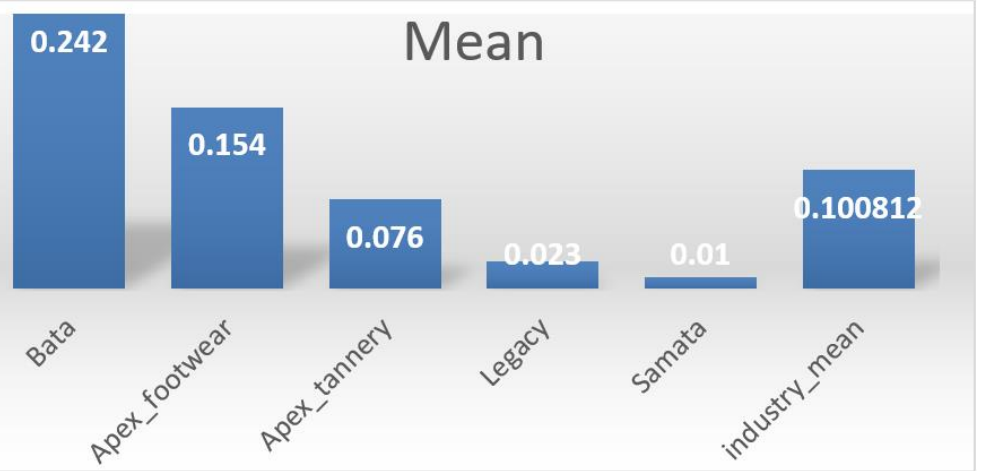

Figure 3: Average efficiency ratio

Here, Table 4 contains the ratio of Market value of Equity (MVE) to Book value of debt (BVD). This ratio is also known as the Volatility ratio, which explains the risk or uncertainty related with the fluctuation in the market price of a security. It also indicates the confidence of the stockholders over the performance of the company. In our study, Samata has the highest volatility ratio of 5.29, indicating a high possibility of changes in stock price within a short time span in either direction. Apex Footwear on the other hand has the lowest (0.334), indicating the stock price is steadier during the observed period.

Table: 4

\begin{tabular}{|lcccccc|}
\hline Year & Bata & Apex footwear & Apex tannery & Legacy & Samata & Industry mean \\
\hline $2010-2011$ & 0.65 & 0.4 & 1.31 & 0.836 & 0.49 & 0.7372 \\
$2011-2012$ & 0.87 & 0.39 & 1.73 & 0.836 & 0.2 & 0.8052 \\
$2012-2013$ & 0.96 & 0.35 & 2.79 & 0.823 & 9.9 & 2.9646 \\
$2013-2014$ & 1.23 & 0.27 & 2.78 & 1.09 & 9.3 & 2.934 \\
$2014-2015$ & 1.31 & 0.26 & 1.77 & 1.06 & 6.56 & 2.192 \\
Mean & 1.004 & 0.334 & 2.076 & 0.929 & 5.29 & 1.9266 \\
Std. Deviation & 0.2692 & 0.0658 & 0.6718 & 0.1338 & 4.6876 & \\
\hline
\end{tabular}




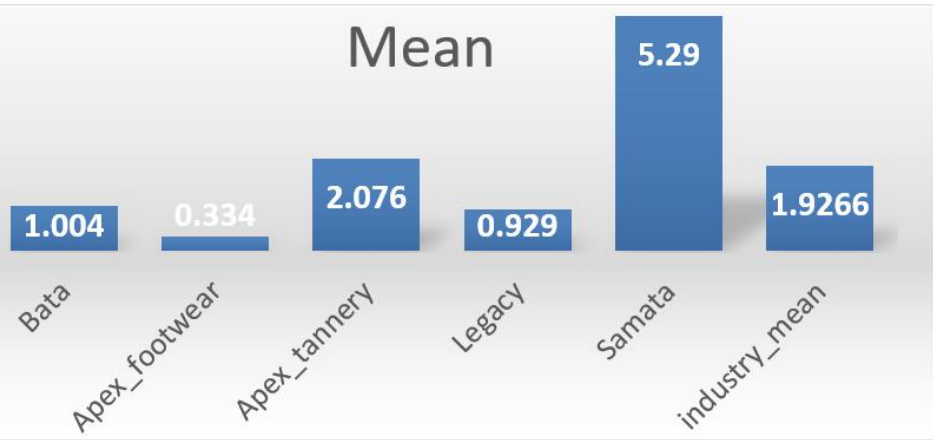

Figure 4: Average volatility ratio

This table indicates the capacity of the companies to generate sales by utilizing their assets, i.e. the ratio between total sales and total asset. This is also known as average asset turnover ratio. In our findings, Apex Tannery has the highest mean value of $208.8 \%$, indicating a very efficient utilization of its asset in generating revenue. Bata and Apex Footwear are performing in similar manner. On the other hand Samata and Legacy are found not in sync with the industry, where the industry average shows a mean value of $96.28 \%$ which is consistent during the observed period.

Table: 5

\begin{tabular}{|lcccccc|}
\hline Year & Bata & Apex footwear & Apex tannery & Legacy & Samata & Industry mean \\
\hline $2010-2011$ & 1.93 & 1.32 & 1.56 & 0.37 & 0.07 & 1.05 \\
$2011-2012$ & 1.32 & 1.19 & 1.92 & 0.034 & 0.12 & 0.9168 \\
$2012-2013$ & 1.56 & 1.14 & 2.26 & 0.316 & 0.93 & 1.2412 \\
$2013-2014$ & 0.37 & 0.93 & 2.55 & 0.318 & 0.36 & 0.9056 \\
$2014-2015$ & 0.07 & 0.88 & 2.15 & 0.211 & 0.19 & 0.7002 \\
Mean & 1.05 & 1.092 & 2.088 & 0.2498 & 0.334 & 0.9628 \\
Std. Deviation & 0.7953 & 0.1838 & 0.3721 & 0.1338 & 0.3508 & \\
\hline
\end{tabular}

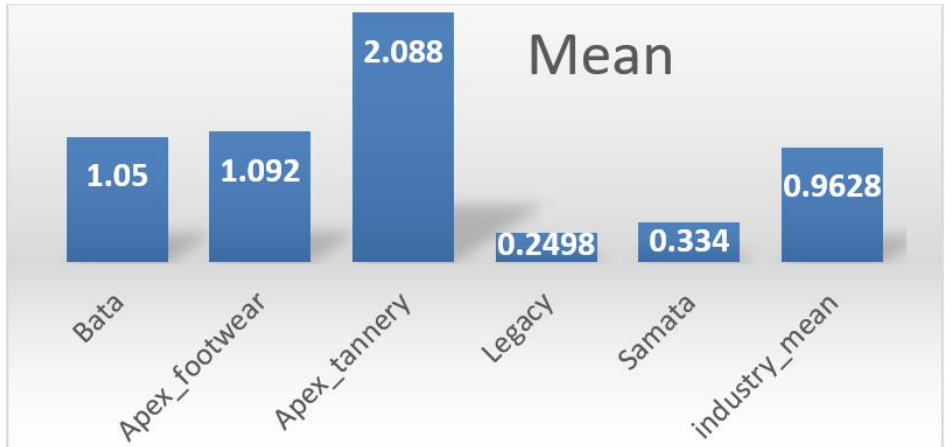

Figure 5: Average asset turnover ratio

Table 6 here contains the calculated Z-score of the listed footwear companies in Bangladesh. According to our findings Apex Tannery has the highest average Z-score (4.51) and consistent good performance. Bata has the next best score (4.13). Samata has the average Zscore of 3.46, where it shows in the initial years of the business (2011 and 2012) the company seems to have faced financial distress. But later in 2013 and onwards, the company managed to reach the safe zone. 
Apex footwear on the contrary is in the grey zone scoring an average Z-score of 2.16. In 2011 the company was in a safe position but gradually in the later years of the observed period, it faced financial difficulties and landed in distress zone.

Lastly, Legacy Footwear is suffering from financial distress from very beginning of the observed period, with 1.55 average Z-score.

Table: 6

\begin{tabular}{|l|l|c|c|c|c|c|}
\hline Year & Bata & Apex footwear & Apex tannery & Legacy & Samata & Industry mean \\
\hline $2010-2011$ & 3.80 & 2.99 & 3.38 & 1.63 & 0.15 & 2.39 \\
\hline $2011-2012$ & 4.07 & 2.89 & 4.12 & 1.25 & -0.022 & 2.46 \\
\hline $2012-2013$ & 4.11 & 1.96 & 5.30 & 1.56 & 7.02 & 3.99 \\
\hline $2013-2014$ & 4.31 & 1.58 & 5.53 & 1.71 & 5.99 & 3.82 \\
\hline $2014-2015$ & 4.36 & 1.40 & 4.21 & 1.60 & 4.14 & 3.14 \\
\hline Mean & 4.13 & 2.16 & 4.51 & 1.55 & 3.46 & 3.16 \\
\hline
\end{tabular}

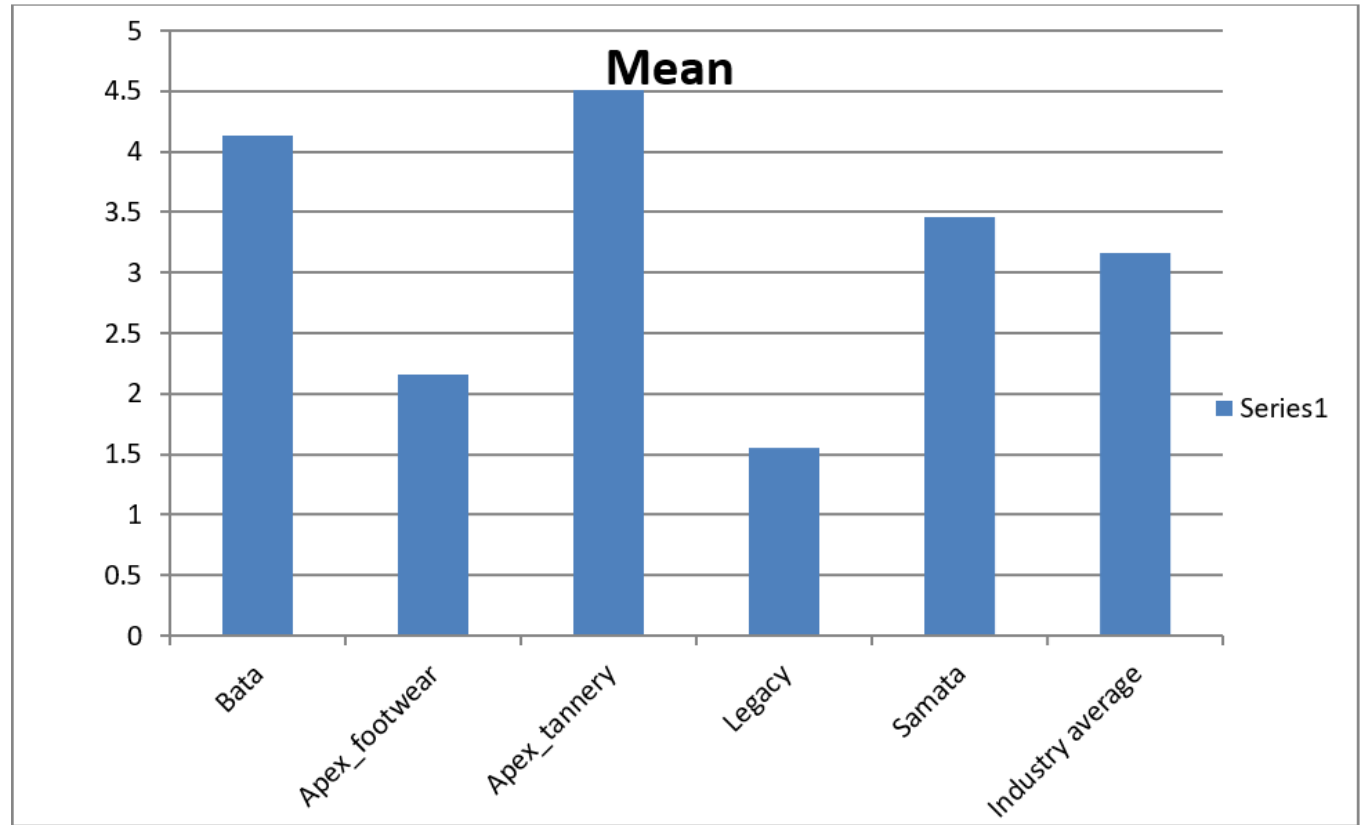

Figure 6: Average Z-score value

\section{CONCLUSION}

The stakeholders are interested in a company which is financially sound. They look forward to understand the financial performance and position of the company as well as their possibility of bankruptcy to make decision. The Altman's Z-score model is the most widely used tool to help the stakeholders.

In our study, we have selected the Footwear industry of Bangladesh and analyzed its possibility of bankruptcy using the Altman's Z-score. We have found that, among the 5 listed companies, Bata and Apex Tannery are showing consistent performance throughout the observed period. These two companies are found to be financially sound as they have a higher Z-score than the benchmark (2.99). They have maintained a stable condition 
regarding liquidity, profitability, efficiency, volatility and asset turnover. So it can be said these companies have no possibility to face financial distress and bankruptcy in near future.

Samata on the other hand has struggled in the initial years, but found itself in the safe zone in the recent years. This company now, is also in no threat of immediate bankruptcy.

In contrast, Apex Footwear started the observed period (2011) with financial stability but ended up with financial distress (2014 \& 2015). As a result the company is in the grey zone having its Z-score (2.16) in between 1.80 and 2.99. The company is suffering from excessive debt compared to the current assets, which makes the company more prone to liquidity crisis. This can lead to a nonpayment of current obligations. If the situation is not improved the company might face bankruptcy in near future.

Legacy footwear is in the distress zone (1.55) which is below 1.8. From the very beginning of the observed period, Legacy is suffering in cases of profitability, efficiency and asset turnover. This situation creates a threat for immediate bankruptcy, if the management doesn't take remedial action.

After the detailed study of 5 listed companies, it can be said that the overall footwear industry is financially sound though some companies are still struggling.

So, we can say that this study can help different groups of stakeholders regarding their individual decision making. The managers of the companies can use the finding to improve their performance, where, shareholders can choose investment options carefully and all other related groups can safeguard their interest.

\section{REFERENCES}

Alkhatib, K. and Al Bzour, A.E. (2011). "Predicting Corporate Bankruptcy of Jordanian Listed Companies: Using Altman and Kida Models", International Journal of Business and Management, 6(3): 208-215.

Al-Rawi, K, Kiani, R. and Vedd, R.R. (2008). “The Use of Altman Equation for Bankruptcy Prediction in an Industrial Firm (Case Study)", International Business \& Economics Research Journal, 7(7): 115-127.

Altman, E.I. (1968). "Financial Ratios, Discriminant Analysis and the Prediction of Corporate Bankruptcy", The Journal of Finance, 23(4): 589-609.

Begley J., Ming J. and Watts S. (1996). “Bankruptcy classification errors in the 1980s: An empirical analysis of Altman's and Ohlson's models". Review of Accounting Studies, 1(4):267-284.

Chandra, Prasanna (1995). The Investment Game, New Delhi, McGraw Hill Publishing Co. Ltd. pp.172

Chen K. H. and Thomas A. Shimerda. (1981). "An Empirical Analysis of Useful Financial Ratios", Financial Management, 10(1): 51-60.

Collins, R. A., An Empirical Comparison of Bankruptcy Prediction Models, Financial Management, summer 1980, v9 (2), 52-57.

Empirical Investigation Using Z-Score". American Journal of Trade and Policy 1.1 (2014): 16. Web.

Hannan, Md. Sheikh, Shaheed, A. Miah, and Abdus, M. (1979). Financial Position and Performance Analysis of Bangladesh Shilpa Bank. Islamic University Studies (Part C),1(2),pp.207-255.

Helfert, A., (1991), Techniques of Financial Analysis, 7th Ed, Homewood, IL, Irwin. Ch 1.

Horne, V., and James, C., (1998), Financial Market Rates and Flows, 5th Ed, Prentice-Hall. Ch 14.

Hossain, Md. Kamal and Syed Moudud Ul Huq. "Analysis Of Credit - Strength Of Cement Industry in Bangladesh". Management Studies and Economic Systems 1(2).Autumn 2014 (2014): 97-114. Print. 
Jahur, M. S. and Parveen, J. A. (1996). An Analysis of Financial Performance of Public Enterprises-A Case Study of Chittagong Steel Mills Ltd, Chittagong University Studies (Commerce), 12, pp. 173184.

Jahur, Mohammad Saleh \& Uddin, Mohammad Mohi (1995). 'Measurement of operational performance through ratio analysis - A case study of Usmania Glass Sheet Factory Ltd. Chittagong', Chittagong University Studies (Commerce), vol.XI, pp.245-255

Kida, C.Y. (1998). "Financial Ratios as Predictors of Bankruptcy in Japan: An Empirical Research", Journal of Finance, 123: 589-609, cited in Alkhatib, K. and Al Bzour, A.E. (2011). "Predicting Corporate Bankruptcy of Jordanian Listed Companies: Using Altman and Kida Models", International Journal of Business and Management, 6(3): 208-215.

LIN, Wen-Cheng, LIU, Chin-Feng, CHU, Ching-Wu (2005). 'Performance efficiency evaluation of the Taiwan's Shipping Industry: An Application of DEA', Proceeding of the Transportation Studies, Vol.5, pp.467-476

Mizan, A., \& Hossain, M. (2014). Financial Soundness of Cement Industry of Bangladesh: An Empirical Investigation Using Z-score. American Journal Of Trade And Policy, 1(1), 16 - 22.

Mizan, A.N.K., Amin, M.R. and Rahman, T. (2011). "Bankruptcy Prediction by Using the Altman Zscore Model: An Investigation of the Pharmaceutical Industry in Bangladesh", Bank Parikrama, 36(2-4): 33-56.

Mizan, A.N.K., Amin, M.R. and Rahman, T. (2011). "Bankruptcy Prediction by Using the Altman Zscore Model: An Investigation of the Pharmaceutical Industry in Bangladesh", Bank Parikrama, 36(2-4): 33-56.

Mossman, C. E., Geoffrey G. Bell, L Mick Swartz, and Harry Turtle, An Empirical Comparison of Bankruptcy Models, The Financial Review, May 1998, v33(2), 35-52.

Pandey, I. M. (1979). Financial Management, Vikas Publishing House Pvt. Ltd, New Delhi, pp.109-116

Pandey, I.M. (2004) Financial Management, 9th Edition, New Delhi: Vikas Publishing House PVT Ltd.

Ramaratnam, M.S. and Jayaraman, R. (2010). "A study on measuring the financial soundness of select firms with special reference to Indian steel industry - An empirical view with Z score", Asian Journal of Management Research, Online Open Access publishing platform for Management Research, pp. 724-735.

Shirata, C.Y. (1998). "Financial Ratios as Predictors of Bankruptcy in Japan: An Empirical Research", Paper presented in the Second Asian-Pacific Interdisciplinary Research in Accounting Conference Program (APIRA98) held on 4th - 6th August, 1998, available at http://www3.bus.osakacu.ac.jp/apira98/archives/pdfs/31.pdf; retrieve on January 25, 2012.

Shumway, T. (2001). "Forecasting bankruptcy more accurately: A simple hazard model", Journal of Business, 74(1): 101-124, cited in Chava, S. and Jarrow, R.A. (2004). "Bankruptcy Prediction with Industry Effects", Review of Finance, 8: 537-569.

Wen-Cheng LIN, LIU, Chin-Feng, CHU, Ching-Wu (2005). 'Performance efficiency evaluation of the Taiwan's Shipping Industry: An Application of DEA', Proceeding of the Transportation Studies, Vol.5, pp.467-476

Wood, frank and Sangster Alan (2002). Financial Accounting: A New Perspective, 9th Edition, London: Prentice Hall.

Zmijewski, M. E. (1984). "Methodological issues related to the estimation of financial distress prediction models", Journal of Accounting Research, 22(1): 59-82, 